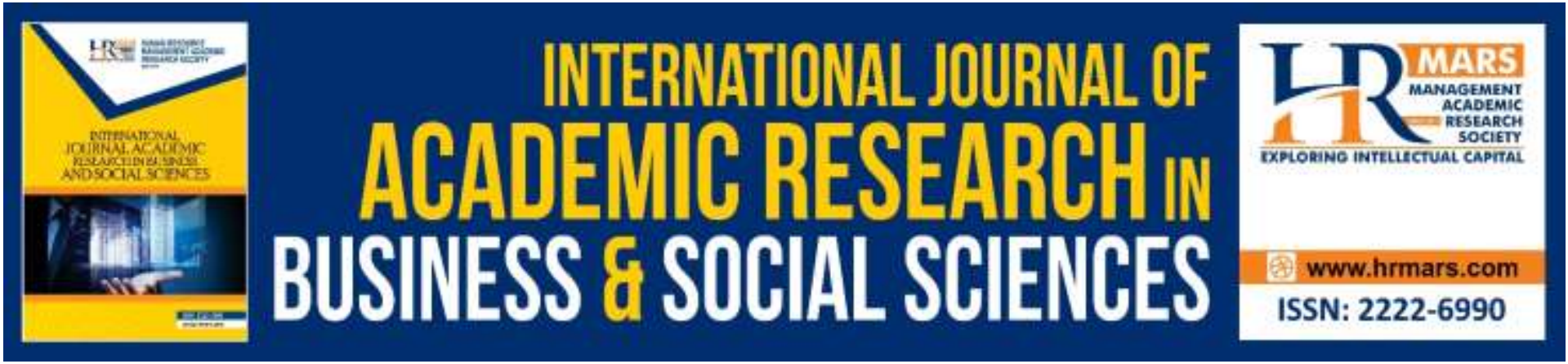

\title{
Determining the Influence of HR practices on Organizational Innovation A Case of Higher Education Sector of Punjab, Pakistan
}

\section{Muskan Hussain, Shama Imam, Shaista Hussain, Tasawar Javed}

To Link this Article: http://dx.doi.org/10.6007/IJARBSS/v9-i9/6318

DOI: $10.6007 /$ IJARBSS/v9-i9/6318

Received: 20 July 2019, Revised: 10 August 2019, Accepted: 01 September 2019

Published Online: 27 September 2019

In-Text Citation: (Hussain, Imam, Hussain, \& Javed, 2019)

To Cite this Article: Hussain, M., Imam, S., Hussain, S., \& Javed, T. (2019). Determining the Influence of HR practices on Organizational Innovation A Case of Higher Education Sector of Punjab, Pakistan. International Journal of Academic Research in Business and Social Sciences, 9(9), 495-513.

\section{Copyright: (C) 2019 The Author(s)}

Published by Human Resource Management Academic Research Society (www.hrmars.com)

This article is published under the Creative Commons Attribution (CC BY 4.0) license. Anyone may reproduce, distribute, translate and create derivative works of this article (for both commercial and non-commercial purposes), subject to full attribution to the original publication and authors. The full terms of this license may be seen

at: http://creativecommons.org/licences/by/4.0/legalcode

Vol. 9, No. 9, 2019, Pg. 495 - 513

Full Terms \& Conditions of access and use can be found at http://hrmars.com/index.php/pages/detail/publication-ethics 


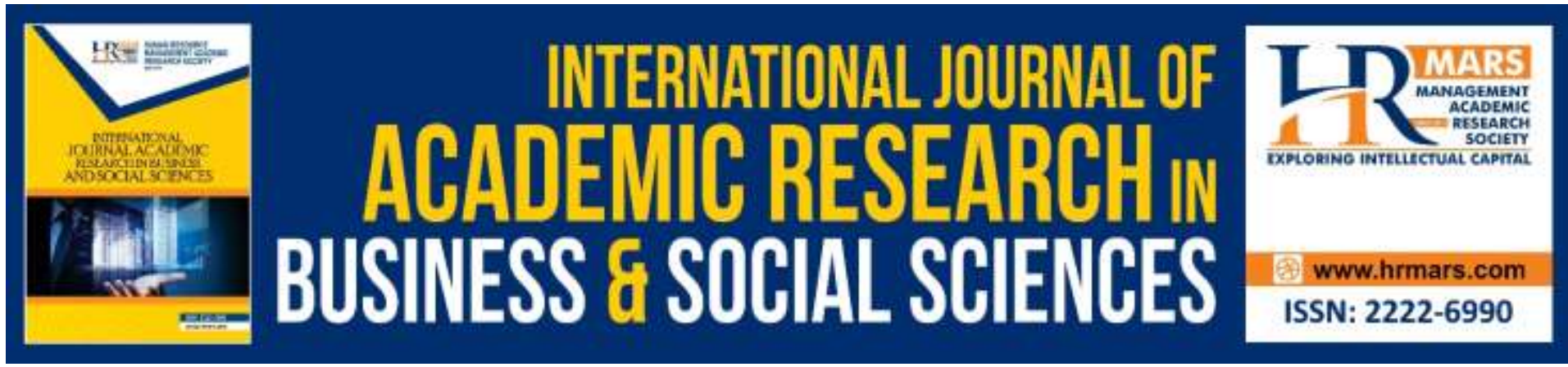

\title{
Determining the Influence of HR practices on Organizational Innovation: A Case of Higher Education Sector of Punjab, Pakistan
}

\author{
Muskan Hussain \\ Research Scholar, NCBA\&E, Bahawalpur Campus, Pakistan \\ Shama Imam, Shaista Hussain \\ Visiting Lecturer, The Islamia University of Bahawalpur, Pakistan
}

Tasawar Javed

Assistant Professor, Department of Management Sciences, The Islamia University of

Bahawalpur, Pakistan

\begin{abstract}
The prime objective of the study is to explain the phenomenon of organizational innovation influenced by human resource practices. The moderating role of managerial ties is explained between relationship of human resources practices and organizational innovation. Human resource management is critical for business success strategically and important for organizational knowledge, skills, abilities and behavior of employees that have potential to influence performance of firm. Researchers have found that organizational success and innovative capabilities most likely to be initiated by the level of technology adoption and implementation for organizational process change and success. Technological advancements assist organizations to change operational and managerial processes for meeting objectives of firms to be innovative and successful. The current study focuses on human resources assets as predictors of organizational innovation capability and success in higher education sector of Pakistan. The study expresses the concept and dimensions of organizational innovation and its' predictors including HR practices relevant in HES. The data was collected from 205 employees of different campuses of HES through questionnaire and analyzed by Smart PLS. The study found positive significant relation between HR practices and organizational innovation, further findings of the study useful for HES employees to initiate best HR practices at their firm to adopt technological advancements to be innovative and to gain competitive edge in highly competitive environment. The moderating role of managerial affiliation and aspect did not moderate the relations in present study.
\end{abstract}

Keywords: Organizational Innovation (OI), Human Resource (HR), Higher Education Sector (HES) 


\section{Introduction and Background}

Business success depends largely on Human Capital development as critical factor. Knowledge, skills and abilities of employees are stated as important resources for organizational success and plays vital role in performance of organization. Organizational success requires effective human resources and human capital to harvest their knowledge, skills and abilities for accomplishment of their goals (Osman \& Galang, 2011; Zakaria, Ishak, Arshad, Abdullah, \& Ahmad, 2018). Enhancement of knowledge, skills and abilities at HES are highly encouraged to gain competitiveness, high productivity and performance. Appropriate strategy for development of HR needs to be focused by HES for gaining objectives and success. Literature considered large and entrepreneurial business sectors for implementing $H R$ practices; these studies included DAUD (2006) conducted study on link if HR and performance in large organizations; Ekhsan Abang Othman (2009) conducted studies on strategic integration of HR practices in business firms; further studies in the same perspective have been conducted by various researchers including (Becker, Huselid, Becker, \& Huselid, 1998; Ekhsan Abang Othman, 2009; Hemdi, 2006; Jackson \& Schuler, 1995). HR practices play vital and important role in SMEs success and performance and for encouragement of innovation. Studies are required to conduct with best HR practices in the context of organizational innovation which is needed at HES level as in previous studies is overlooked (Zakaria et al., 2018). Human resources are valuable resources for organizational success and HR practices significantly influential in operations and success of firms (Abdullah, Ahsan, \& Alam, 2009) at higher education level. The current study intends to consider specific HR influential practices for organizational innovation and success in HES sector of Pakistan. The study claims that specific HR practices can encourage organizational innovation at HES level and contribute for organization success.

Literature has focused on various factors which are contributive towards organizational success and innovative capability, these factors entails individual factors, organizational and environmental factors. Previous literature focused largely on key factors of organizational influences related to organizational factors (Vincent, Bharadwaj, \& Challagalla, 2004); various researchers have focused on HR practices for key factors for innovation Chen and Huang (2009) with mediating role of knowledge management; Nasution, Mavondo, Matanda, and Ndubisi (2011) focused on drivers of innovation and found that learning and market orientation are influential factors for innovation; Ling and Mohd Nasurdin (2010) found that management practices significantly influential for organizational innovation. Eisenhardt and Martin (2000) studied on resource based view of the firm for innovations and reported that strategic decision making and alliance are found to be influential for organizational dynamic innovations, further, Rhee, Park, and Lee (2010) found that market orientation and learning capabilities influence organizational innovation in SMEs of South Korea. Hence, previous researchers have found various different organizational factors and HR factors found to be influential for organizational innovation and for competitive edge in market place.

There are few empirical studies with the focus on HR practices as influencing towards the innovation capabilities of firms. The current study will be one of pioneer study to examine influence of specific HR practices on organizational innovation in HES sector of Pakistan. The study intends to bridge the gap of association of HR practices to organizational innovation. Empirical evidence found to be inconclusive in establishing the link of various key driving factors and organizational innovation which further discussed in literature with performance. The positive effects have been reported by Keskin (2006) among learning orientation and innovation in SMEs. Researchers Mavondo, Chimhanzi, and Stewart (2005) conducted study 
to examine the relationship between HR practices, market orientation and performance while considering innovativeness as moderating effect. The study found positive significant relation. Contrary, negative effects have been reported by other researchers including Hultink and Atuahene-Gima (2000) examined the relationship with performance of SMEs; further, (Vermeulen, De Jong, \& O'shaughnessy, 2005) reported negative effects in examining the innovativeness and performance as innovation in product or service has no effect on performance. The inconsistency in results among constructs suggest moderator to examine the relation more specifically (Rosenbusch, Brinckmann, \& Bausch, 2011).

Previous studies have used various moderating variables in examining the relation of predictors of organizational innovation and performance such as social capital, managers' relations, networks, linkages with customers, suppliers and competitors (Lu, Zhu, \& Bao, 2015). Managerial association and links are also used as moderators for examining the relations between predictors of innovations (Van Laere \& Heene, 2003) and stated as one of the most important construct to be influential in any sector (Farinda, Kamarulzaman, Abdullah, \& Ahmad, 2009). The present study is novel in explaining the role of best HR practices taken in present study including effective communication \& information sharing, Training \& Development and compensation among higher education sector of Pakistan. The study contributes to explain the relationships between independent variables and dependent variable with moderating role of managerial ties among higher education sector of Punjab, Pakistan.

\section{Higher Education sector of Pakistan}

Higher education and learning have crucial importance in entire life of human being as education considered as an essential and integral part. Higher education found to be supportive for countries and nation to be competitive, productive, generation of skilled workforce and innovative by application of latest technology and ideas. The higher education sector contributes to innovation and research which is considered as vital role that supports in social and economic growth of nation. Higher education sector contributes centrally for innovation, research, learning and socially inclined society by increasing ethics, morality, economic growth and development of nation and individuals. The strategic significance of higher education can be seen as an investment on research education with real time revolution (Aghion, Dewatripont, Hoxby, Mas-Colell, \& Sapir, 2010). Higher education sector plays central role in knowledge generation and sharing that contribute for growth of nation by initiating change in society, influence behavior by valuing individuals and economic strength.

Higher education sector of Pakistan is facing various issues including of not being capable of accomplishing major milestones and targets to provide knowledge based intellectual economy. Lack of all types of resources, financial issues, inappropriate management system and huge population are fewer serious problems and issues that instigate imperfect educational system with problematic nature to deliver irrelevant and wastage services. It has been observed that due to these reasons ineffective and insufficient lower productive culture has established over number of years and have not been addressed. The issues and challenges included lack of study support services, wastage of limited resources, lack of funds and outdated curricula with low recovery (Hassan \& Din, 2019; Wahab, 2016). The other issues raised in tertiary education associated with leadership that negatively affect educational conditions and education of students (Cardno, 2014). 
The current research papers investigates the best HR practices that influence the innovation at higher education sector of Pakistan with moderating role of managerial ties.

\section{Literature Review}

The current part of the study includes the detail discussion about constructs and their relationships in organizational innovation.

\section{Organizational Innovation}

The initiatives for new and emerging ideas at organizations are always encouraged as innovative ideas found to be fruitful in accomplishing organizational goals and to gain success at any business level. Organizational innovation is referred as acceptance, adoption and implementation of new ideas at firms in terms of product, process or managerial innovative initiatives (Che-Ha \& Mahmood, 2012).

Competitive environment and global presence of firms has changed the basis of competition and innovation plays vital role for firms to maintain their edge and market share. Innovation is considered as lifeblood for businesses in literature, and largely evident that continuous creation, managing and implementation of newly creative ideas at business firms assist them to increase their performance and helping in survival as well as in maintain competitive edge in turbulent environment. (Martínez-Costa, Jimenez-Jimenez, \& Castro-del-Rosario, 2018). Firms need to focus on innovations as they faced global competition due to technological advancements, global phenomenon and dynamic rapid changes in business strategies, innovative capabilities or competitors and economic environment. The environment instigates firms to adopt innovative ideas for their survival in limited resources and competitive environment. Manole et al., (2014) stated that small organizations are more inclined towards adoption of advancements and innovative ideas as compare to large organizations. Lack of resources at HES sector may slow down the implementation of innovativeness. Simple structure of SMEs found to be helping and assisting in adoption of new ideas in their business, as less hierarchy found to be faster, responsive and flexible in adoption of creative ideas in response to rapidly changing environment. Quick growth at SMEs are possible and observed as previously identified factors found to be main engine for adoption of new technology and innovative ideas (Love \& Roper, 2015).

The purpose of innovation in organizations serves to sustain and grow their products or services in competitive environment (Baregheh, Rowley, \& Sambrook, 2009; Mafabi, Munene, \& Ahiauzu, 2015). The firms harvest various benefits by implementing technological advancements for products or services, structural changes, administrative tasks and performance by increased innovative capabilities. (Damanpour \& Schneider, 2006; Zakaria et al., 2018). Organizational innovation found to be very crucial to give distinction to a firm for gaining competitive edge (Lee \& Hsieh, 2010).

Researchers have presented different viewpoints for innovation in concept, innovativeness, capacity of firm to innovate and capability of innovation (Damanpour \& Schneider, 2006; Zakaria et al., 2018). The basis for the claim based on the study of Hurt, Joseph, and Cook (1977) in which conceptualization of innovativeness from two viewpoints; the first viewpoint clearly states behavioral variable such as adoption of innovation in firm; second view point states willingness of organization for adopting the change in current procedures. Further, two constructs have been introduced under the umbrella of innovation; the innovation in the study of Hurley and Hult (1998) is referred as openness for newly and emerging ideas embedded in culture of organization. Capacity of innovation is defined as the organizational 
willingness and abilities of organization for adoption of new technology implementation, new ideas initiative, processes change and development in production or services with remarkable success (Tajeddini, 2010). Further the previous study included the implementation of new ideas for unique products and services to capture market and perform better in competitive environment.

\section{Product Innovation}

Researchers have discussed and defined three types of innovation which includes product innovation, process innovation and managerial innovation.

Organizations focus on their customer and strive to fulfill demand of their market, organization initiate develop their products or services with innovative ideas for meeting external demands (Damanpour \& Schneider, 2006). Wang, Yen, Tsai, and Lin (2008) described product innovation as development of new products or services with significant changes as compare to market and competitors; initiation of new and emerging ideas on appropriate time with meaningfulness and novelty. The impact of product innovation offered by organizational management occupy market share, grasp benefits and compete in global market with competitive edge (Nasution et al., 2011).

\section{Process Innovation}

Novelty in production system of product or service, the new or changed process to perform organizational operations considered under the concept of process innovation, organizations focus to initiate changes for adoption of technology to gain benefits in competitive environment (Damanpour \& Schneider, 2006). Innovative capabilities of organization includes innovative initiatives in process change for utilization of resources effectively and efficiently for meeting creative production through which organizational success and sustainability determines by managerial apex (Wang et al., 2008).

Che-Ha and Mahmood (2012) conceptualized innovation in terms of update organizational operational process with novelty and strategies, financial initiatives, structural changes, latest equipment installation to transform raw to finished products or services and all activities for comprehensive production cycle.

\section{Managerial Innovation}

Che-Ha and Mahmood (2012) defined the concept of innovation with association with managerial aspect; managerial or administrative innovation ideas are referred as system of managing resources, conducted various operational processes, procedures and techniques which found to be influential in relation to employee and achievement of goals. Further, Nasution et al. (2011) defined managerial innovation as conducting firms' operations with novelty and newly emerged processes in operations. This type of innovation includes changed organizational policies, employee attitudes, working practices and HR relations including reward strategy and quality implementation of these practices in adoption of latest technological advancements to maintain good quality (Che-Ha \& Mahmood, 2012).

Small and medium sized firms play vital role in economic development and strive to maintain their position in competitive environment; for the said reasons firms need to innovate continuously in all aspects to gain competitive edge (Akman \& Yilmaz, 2008). HES must be capable for selection, development, sustainability, modification and enhanced technological products covers under the umbrella of innovative capability. 


\section{HR practices and Organizational Innovation}

Various researchers have identified multiple predictors of organizational innovations which are grouped as organizational entities, organization itself, and additional organizational factors.; whereas managers, leader and agents comes under organizational entities; size, structure and policies are defined as organization itself and environmental factors as extra or additional factors (Hult, Hurley, \& Knight, 2004). Further, predictors or antecedents of organizational innovation are identified as structure and leadership (Siengthai \& Bechter, 2001); market orientation (Hult et al., 2004; Lin, Peng, \& Kao, 2008; Nasution et al., 2011); learning and development (Calantone, Cavusgil, \& Zhao, 2002; Lin et al., 2008; Nasution et al., 2011); entrepreneurship (Nasution et al., 2011; Rhee et al., 2010); market dimensions (Wang et al., 2008) and HR practices (Hashim, Ali, \& Fawzi, 2005; Jimenez-Jimenez \& Sanz-Valle, 2008; Lopez-Cabrales, Pérez-Luño, \& Cabrera, 2009).

Literature has empirically examined all above stated predictors for organizational innovation in different work setting, organization in various countries including, Taiwan, USA, China, EU and Asian context. The current study focuses on HR practices including effective communication and information sharing, compensation strategy and Training and development of employees as predictors of organizational innovation for HES of Pakistan.

HR practices have been emerged in literature as influential predictors of organizational innovation by various researchers as addressed in previous portion of the current paper. Various scholars (Hashim et al., 2005; Jimenez-Jimenez \& Sanz-Valle, 2008; Lopez-Cabrales et al., 2009) has conducted studies to investigate relations of HR practices in various organizational success factors. Shipton, West, Dawson, Birdi, and Patterson (2006) conducted study on the effect of globalization and rapidly changing and challenging business environment and involvement of HR practices as further leads towards innovation initiatives in products and services in higher education sector. Employees' management and related issues are handle by HR practices which includes attraction, development and retention of employees for organizational success and maintenance of market competitive position (Jackson \& Schuler, 1995; Zakaria et al., 2018).

The current study focused on HR practice specifically 'communication and information sharing', compensation and 'training and development' at HES for initiate organizational innovations. The literature has addressed the issue of HR practices in various context and in relation to organizational innovative capabilities but empirical evidences are not sufficient to examine the relation and strength of $H R$ practices as stated above to organizational innovation (Smith, Courvisanos, Tuck, \& McEachern, 2011; Zakaria et al., 2018). Literature has addressed relation of HR practices to technology innovation, researchers focused on EU and western countries, relation of HR with high-tech organization and lack of empirical studies (Zakaria et al., 2018). Innovative behaviors can be predicted through HR practices, HR management can develop effective managerial policies and initiatives to encourage suitable and required behaviors of employees for creation and implementation of knowledge (Shipton et al., 2006).

Researchers have identified that HR practices as important for innovation, development of innovative initiatives and creating values for customers (Nasution et al., 2011). Effective HR policies and practices found to be influential for encouraging employees to create ideas, development of knowledge and implement changes in organization (Ling \& Mohd Nasurdin, 2010). Significant and positive relation has been identified between innovation capabilities and HR practices. These practices includes rewards strategy, creativity training, sharing of skills, valuing people, development of innovation capabilities, effective recruitment 
resources, continuous learning and job security for accelerating innovation activities for organizational success and maintenance in competitive environment.

The present study includes three HR practices including specifically 'communication and information sharing', compensation and 'training and development' at HES for initiate organizational innovations.

\section{Communication and Information sharing and Organizational Innovation}

Information sharing and effective communication enhance working relation and increase certainty among entities of organizations. The establishment of such working relation at workplace creates positive climate and encourage employees for commitment towards adoption of technology for organizational innovation, collaboration among various departments of organization for innovative production process (Vlachos, 2009; Zakaria et al., 2018). Murat Ar and Baki (2011) stated that effective HR practices enable employees to generate new and creative ideas which further leads organizations and firms at HES level for innovation. Information sharing and effective communication enables organizations to grow while including innovative solutions to gain competitive edge and to gain organizational success (Zakaria et al., 2018).

\section{Training \& Development and Organizational Innovation}

Employees enhance their knowledge, skills and abilities through continuous learning and training; which enable employees to enhance talent and to gain multi-skills capability and enhanced capabilities of employees enable organization to implement innovation for competitive edge (Jimenez-Jimenez \& Sanz-Valle, 2008). Through training and development the enhancement of capabilities of employees takes place for accepting and adoption of new knowledge, learning new skills, enhancing abilities will be contributive towards creation of innovative activity (Diaz-Fernandez, Bornay-Barrachina, \& Lopez-Cabrales, 2015). The effective training and learning activities at organization enable employees to compete on the basis of knowledge, skills and abilities and enable them to be competitive and initiate innovative activities for organizational success (Shipton et al., 2006; Zakaria et al., 2018).

\section{Compensation and organizational Innovation}

Compensation or remuneration or reward strategy of organization found to be significant influential towards the motivational aspect of employees at any workplace. Reward strategy and compensating employees according to their KSAs and contribution of employees towards innovations and creativity at firms to be competitive in rapidly changing environment (Chen \& Huang, 2009). Innovation is stated as driving and key factor for organizational success and survival. Remuneration and rewards found to be motivational factor for employees to be innovative and contribute towards innovative activities for developing more products and to generate creative ideas (Gupta \& Singhal, 1993; Zakaria et al., 2018). Creativity at organizations introduced by employees largely motivated by rewards strategies; which includes financial and non-financial attractions, promotions and employee recognition.

\section{Moderating Role of Managerial Ties}

Baron and Kenny (1986) described the nature of moderator as variable that influence the strength of relation between independent and dependent variables. It considered as third variable that affect the relationship among two variables. The present study entails managerial perspective as moderating variable between independent variables of study 
(effective communication and information sharing, training and development and compensation) and dependent variable (organizational innovation).

The moderating role have been examined in prior studies by managerial aspect conducted by (Walter, Auer, \& Ritter, 2006; Zakaria et al., 2018). Further, studies have been examined the moderating role of managerial ties between entrepreneurial orientation and performance among various diverse industries. The studies have reported that managerial aspect and competencies strengthen the relationship between entrepreneurial orientation and performance of firm. The studies conducted similar investigations that management role strengthen the relationship between functions of firms and performance bring benefits among various industries (Boso, Story, \& Cadogan, 2013). The impact of networking among firms have been examined and found that it strengthened the relationship between networking capability and performance. The various factors such as entrepreneurship don't influence the performance but managerial ties moderate the relationship between networking capability and performance (Walter et al., 2006). Thus, it is important to investigate the moderation effect of managerial ties between HR practices and organizational innovation as novelty of the present study.

\section{Research Framework}

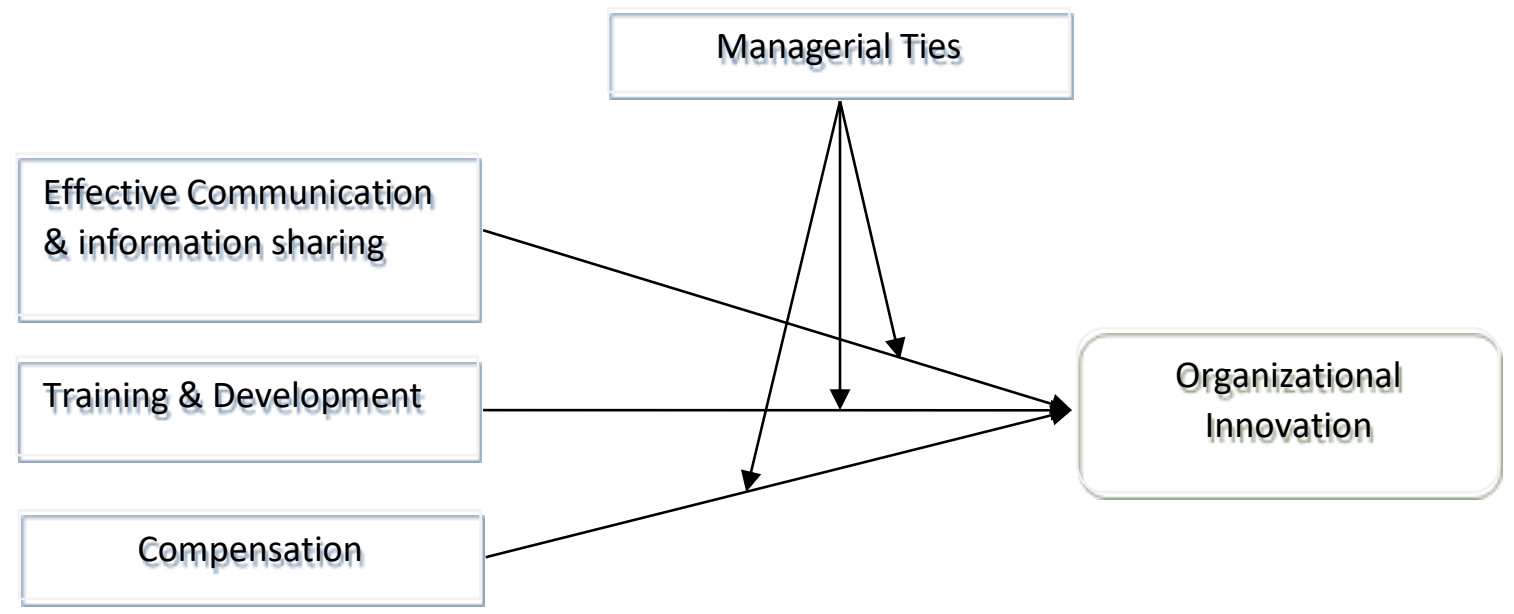

Fig 1: Proposed Framework

\section{Hypothesis Development}

H1: There is significant positive relation between effective communication, information sharing and organizational innovation

H2: There is positive and significant relation between T\&D and organizational innovation

H3: There is positive and significant relation between compensation and organizational innovation

H4: Managerial Ties moderate the relationship between effective communication \& information sharing and organizational innovation

H5: Managerial Ties moderate the relationship between training \& development and organizational innovation

H6: Managerial Ties moderate the relationship between compensation and organizational innovation 


\section{Research Methodology \\ Research Design}

The prime concern of the study is to empirically investigate the relationship between independent and dependent variables with moderating role of managerial intentions and ties. The unit of analysis for present study is individual in public sector universities of south Punjab. They questionnaires were designed for data collection as primary data was required to examine the hypothesized relation and categorized in field with correlation research design or quantitative orientation (Kerlinger \& Lee, 2000).

\section{Population and Sample}

The research study entails effective communication and information sharing, training and development and compensation as independent and best HR practices intended to be investigated influential towards organizational innovation with moderating effect of managerial ties. The data was collected from public universities campuses of south Punjab. The target population was individual lecturers of the universities that are approximately 1000 and according to Krejice and Mogran (1970) table the sample size is 278 as described by (Sekaran \& Bougie, 2016).

\section{Sampling Technique}

Simple random sampling was used which is straightforward method where every respondent have equal chances to be selected for data collection (Hair Jr, Hult, Ringle, \& Sarstedt, 2016). Total 350 questionnaires were distributed and received 205 completed responses that were complete and useable for analysis which shows $58 \%$ response rate.

\section{Measurement Scale}

The measurement scale of the study to examine the hypothesized relationship between independent and dependent variables were adopted from previous studies. The independent variable 'communication and information sharing' was examined on 06 items based scale and adopted from Agarwala (2003). The 04 items measurement scale of compensation was adopted from the study of Agarwala (2003), and 04 items measurement scale of training and developed was adopted from the study of Takeuchi et al., (2007); the 15 items measurement scale of organizational innovation was adopted from the study of Che Ha \& Mohd Said (2012). The 06 items measurement scale was adopted from the study of (Luk et al., 2008).

Five point Likert scale is used to examine the response for constructs of study. The scale includes 5 points from 'Not at all satisfied' as 1 and to 'Very Satisfied' as 5.

\section{Analysis and Discussion}

Smart PLS was used for data analysis in present study. PLS-SEM's techniques Measurement Model and Structural Equation Modeling considered as most powerful statistical model for social sciences to examining the relationships.

\section{Measurement Model}

The present part of the study examines the collected data for its validity through measurement model technique in PLS by executing Algorithm. The results of the study were examined on the base of construct and convergent validity as shown in the table 1 below. The values of table consists of cronbach alpha $\alpha$, convergent validity and average variance extracted (AVE). The cronbach alpha must be higher than 0.7 , convergent validity must be 
higher than 0.6 and AVE should remain higher than 0.5 . The criteria satisfy the reliability and validity of the constructs.

Table 1: Alpha, Composite Reliability and Average variance extracted:

\begin{tabular}{|l|r|r|r} 
& Cronbach's Alpha & Composite Reliability & Average Variance Extracted (AVE) \\
\hline MT & 0.908 & 0.929 & 0.686 \\
\hline OI & 0.911 & 0.925 & 0.506 \\
\hline T\&D & 0.938 & 0.956 & 0.844 \\
\hline cis & 0.807 & 0.852 & 0.517 \\
\hline comp & 0.945 & 0.961 & 0.859
\end{tabular}

\section{Discriminant Validity}

The table 2 demonstrates the discriminant validity as suggested by Fornell and Lacker, (1981). Discriminate validity in diagonal row is shown and correlation must remain higher than relation with other variables. The first value of each column must remain higher than remaining values of each column.

Table 2: discriminant validity

\begin{tabular}{|c|c|c|c|c|c|}
\hline & MT & 이 & TD & cis & comp \\
\hline MT & 0.828 & & & & \\
\hline 이 & 0.589 & 0.711 & & & \\
\hline$T \& D$ & 0.532 & 0.510 & 0.919 & & \\
\hline cis & 0.564 & 0.553 & 0.519 & 0.719 & \\
\hline comp & 0.505 & 0.465 & 0.710 & 0.537 & 0.927 \\
\hline
\end{tabular}

Structural model Assessment: Direct Hypothesis

The following criteria is recommended to assess the structural model in PLS, where the variance in dependent (endogenous) variable is explained by independent (exogenous) variable is indicated and assess by examining the direct relationship as described in hypotheses.

The direct relation between constructs was examined by bootstrapping method of PLS. The direct relation and association was examined and statistics shows that hypothesis $\mathrm{H} 1$ that determines the influence of effective communication and information sharing to be influential to organizational innovation; the results found that $\beta$ value as 0.255 and $t$-value as 3.420 with $\mathrm{p}$ value as 0.001 ; on the base of statistical results hypothesis $\mathrm{H} 1$ is accepted as it found to be significant. The hypothesis $\mathrm{H} 2$ examined the relation between training and development and organizational innovation and statistical figures shows that $\beta$ value as 0.174 and t-value observed as 2.245 with $p$ value as 0.025 ; on the base of statistical analysis $\mathrm{H} 2$ accepted. The hypothesis $\mathrm{H} 3$ examined the relationship between compensation and organizational innovation. The results of the analysis demonstrates that $\beta$ value found to be 0.035 which is very lower and $t$-value found to be 0.443 which is lower than cutoff point with sig value as 0.685 ; on the base of these statistical figures $\mathrm{H} 3$ rejected as found insignificant. 
Table 2: Direct Relationship

Original Sample (O)

T Statistics (|O/STDEV|)

P Values

MT $->$ OI

0.335

4.499

0.000

T\&D $->$ OI

0.174

2.245

0.025

cis $->$ Ol

0.255

3.420

0.001

comp $->$ Ol

0.035

0.443

0.658

\section{Structural Model:}

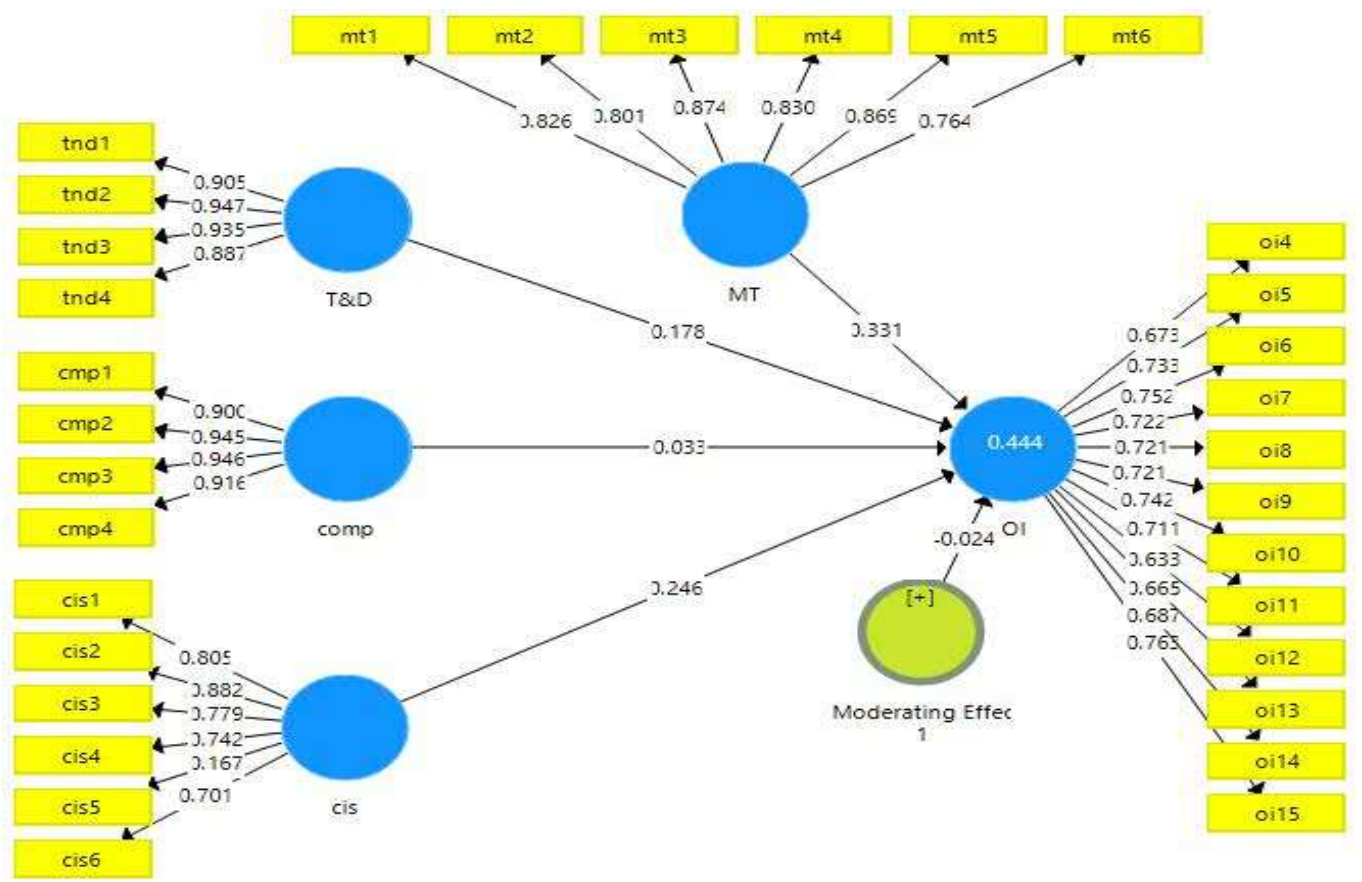

Fig 2: Structural model of study

\section{Moderating Relationship of Managerial Ties}

The moderating effect was examined as hypothesized in proposed framework. The results of the moderating effect presented in table 3 below. The bootstrapping moderation method was used in PLS for analysis of collected data to examine the relationship. 
Table 3: Moderating Effect (CiS*MT $\rightarrow$ OI)

\begin{tabular}{l|r|r|r} 
& Original Sample (O) & TStatistics (|O/STDEV|) & P Values \\
\hline MT -> OI & 0.332 & 4.470 & 0.000 \\
\hline Moderating Effect 1 -> OI & -0.015 & 0.365 & 0.715
\end{tabular}

The statistical values shows that $\beta$ value turned in to negative and $t$-value lower than cutoff point with $\mathrm{p}$-value as 0.715 which is not acceptable and $\mathrm{H} 4$ was rejected as managerial ties didn't moderate between relationship.

Table 4: Moderating effect (TD*MT $\rightarrow$ OI)

\begin{tabular}{l|r|r|r|} 
& Original Sample (O) & TStatistics (|O/STDEV|) & P Values \\
\hline MT -> OI & 0.334 & 4.501 & 0.000 \\
\hline Moderating Effect 1 -> OI & -0.005 & 0.104 & 0.917 \\
\hline T\&D > OI & 0.175 & 2.206 & 0.028 \\
\hline
\end{tabular}

The moderating role was also not observed between training and development and organizational innovation on the base of collected data. On the base of above table 4, statistics figures demonstrate that t-value found lower as 0.104 and $\mathrm{H} 5$ also rejected.

Table 4: Moderating effect (Comp*MT $\rightarrow$ OI)

\begin{tabular}{l|r|r|r} 
& Original Sample $(0)$ & TStatistics (|O/STDEV|) & P Values \\
\hline MT -> OI & 0.331 & 4.308 & 0.000 \\
\hline Moderating Effect 1 -> OI & -0.024 & 0.533 & 0.595 \\
\hline T\&D - > OI & 0.178 & 2.258 & 0.024 \\
\hline cis -> OI & 0.246 & 3.085 & 0.002 \\
\hline comp - > Ol & 0.033 & 0.427 & 0.670
\end{tabular}

The table 4 demonstrates the moderating effect of managerial ties and found that managerial ties don't moderate the relationship, hence on the base of statistical figures of above table 4, hypothesis $\mathrm{H} 6$ also rejected.

\section{Conclusion}

The prime objective of the present study entails the empirical investigation of human resource practices and organizational innovation. The study is one of pioneer in determining the influence of human resource practices with moderating role of managerial ties between HR practices and organizational innovation among universities of Punjab, Pakistan. The present study was conducted on HES of Punjab, Pakistan as higher education sector found to be highly contributive towards GDP and economic growth of the country as stated in earlier part of the study. HES needs to focus on innovation to compete on global level as competition has increased due to global phenomenon. Employees need to upgrade their knowledge, skills and abilities for successful business operations and to gain competitive edge. The study focused HR practices to be focused for better innovative capabilities. There are various researchers have been conducted on external or internal factors as predictors of organizational innovation. Current study focused on specific best HR practices to be focused at HES level to gain better results in competitive environment. Present research focused on communication and information sharing among employees of higher education sector to initiate innovative activities; compensation strategy plays vital role in motivation of 
employees at HES level to enhance their KSA which ultimately contribute for innovation and organizational success. Third and most important predictor is training and development, through extensive training and development employees enhance their experience, knowledge and specific workplace related activities to perform better in adoption of new technological advancements and implementation of latest system for competing on global level. The study found the all three constructs play vital and positive significant role in explaining the organizational innovation. The study helps HES sector to focus on effective communication and information sharing at each level for decision making and implementation of technology and process change. The study contributes towards initiation of valuable and effective remuneration plan for their employees according to their skills and competitors for attracting the new employees and retention of human capital asset. Effective training and development programs must be part of game plan of the firms at HES sector to enhance the knowledge, skills and abilities of workers at each level for responding to external technological changes and environment. In nutshell, HES sector needs to focus on best HR practices as mentioned in study to gain organizational success and be innovative in highly global and competitive environment.

\section{References}

Abdullah, Z., Ahsan, N., \& Alam, S. S. (2009). The effect of human resource management practices on business performance among private companies in Malaysia. International Journal of Business and Management, 4(6), 65.

Aghion, P., Dewatripont, M., Hoxby, C., Mas-Colell, A., \& Sapir, A. (2010). The governance and performance of universities: evidence from Europe and the US. Economic policy, 25(61), 7-59.

Akman, G., \& Yilmaz, C. (2008). Innovative capability, innovation strategy and market orientation: an empirical analysis in Turkish software industry. International Journal of Innovation Management, 12(01), 69-111.

Baregheh, A., Rowley, J., \& Sambrook, S. (2009). Towards a multidisciplinary definition of innovation. Management decision, 47(8), 1323-1339.

Baron, R. M., \& Kenny, D. A. (1986). The moderator-mediator variable distinction in social psychological research: Conceptual, strategic, and statistical considerations. Journal of Personality and Social Psychology, 51(6), 1173.

Becker, B. E., Huselid, M. A., Becker, B., \& Huselid, M. A. (1998). High performance work systems and firm performance: $A$ synthesis of research and managerial implications. Paper presented at the Research in personnel and human resource management.

Boso, N., Story, V. M., \& Cadogan, J. W. (2013). Entrepreneurial orientation, market orientation, network ties, and performance: Study of entrepreneurial firms in a developing economy. Journal of business Venturing, 28(6), 708-727.

Calantone, R. J., Cavusgil, S. T., \& Zhao, Y. (2002). Learning orientation, firm innovation capability, and firm performance. Industrial marketing management, 31(6), 515-524.

Cardno, C. (2014). The functions, attributes and challenges of academic leadership in New Zealand polytechnics. International Journal of Educational Management, 28(4), 352364.

Che-Ha, N., \& Mahmood, A. (2012). Malaysian SMEs in the new economy: Cengage Learning Asia. 
Chen, C.-J., \& Huang, J.-W. (2009). Strategic human resource practices and innovation performance-The mediating role of knowledge management capacity. Journal of Business Research, 62(1), 104-114.

Damanpour, F., \& Schneider, M. (2006). Phases of the adoption of innovation in organizations: effects of environment, organization and top managers 1. British journal of Management, 17(3), 215-236.

DAUD, N. B. (2006). AND FIRM PERFORMANCE: THE MODERATING ROLES OF STRATEGIES AND ENVIRONMENTAL UNCERTAINTIES.

Diaz-Fernandez, M., Bornay-Barrachina, M., \& Lopez-Cabrales, A. (2015). Innovation and firm performance: the role of human resource management practices. Paper presented at the Evidence-based HRM: a Global Forum for Empirical Scholarship.

Eisenhardt, K. M., \& Martin, J. A. (2000). Dynamic capabilities: what are they? Strategic management journal, 21(10-11), 1105-1121.

Ekhsan Abang Othman, A. (2009). Strategic integration of human resource management practices: Perspectives of two major Japanese electrical and electronics companies in Malaysia. Cross Cultural Management: An International Journal, 16(2), 197-214.

Farinda, A. G., Kamarulzaman, Y., Abdullah, A., \& Ahmad, S. Z. (2009). Building business networking: A proposed framework for Malaysian SMEs. International Review of Business Research Papers, 5(2), 151-160.

Gupta, A. K., \& Singhal, A. (1993). Managing human resources for innovation and creativity. Research-Technology Management, 36(3), 41-48.

Jr, H. J. F., Hult, G. T. M., Ringle, C., \& Sarstedt, M. (2016). A primer on partial least squares structural equation modeling (PLS-SEM): Sage publications.

Hashim, M. K., Ali, J., \& Fawzi, D. A. (2005). Relationship between human resource practices and innovation activity in Malaysian SMEs. Jurnal Manajemen \& Bisnis Sriwijaya, 3(6).

Hassan, S., \& Din, B. (2019). The mediating effect of knowledge sharing among intrinsic motivation, high-performance work system and authentic leadership on university faculty members' creativity. Management Science Letters, 9(6), 887-898.

Hemdi, M. A. (2006). Turnover intentions of hotel employees: The role of human resource management practices, trust in organization, and affective commitment. Unpublished PHD thesis, Penang: Universiti Sains Malaysia.

Hult, G. T. M., Hurley, R. F., \& Knight, G. A. (2004). Innovativeness: Its antecedents and impact on business performance. Industrial marketing management, 33(5), 429-438.

Hultink, E. J., \& Atuahene-Gima, K. (2000). The effect of sales force adoption on new product selling performance. Journal of Product Innovation Management: AN INTERNATIONAL PUBLICATION OF THE PRODUCT DEVELOPMENT \& MANAGEMENT ASSOCIATION, 17(6), 435-450.

Hurley, R. F., \& Hult, G. T. M. (1998). Innovation, market orientation, and organizational learning: an integration and empirical examination. The Journal of marketing, 42-54.

Hurt, H. T., Joseph, K., \& Cook, C. D. (1977). Scales for the measurement of innovativeness. Human Communication Research, 4(1), 58-65.

Jackson, S. E., \& Schuler, R. S. (1995). Understanding human resource management in the context of organizations and their environments. Annual review of psychology, 46(1), 237-264.

Jimenez-Jimenez, D., \& Sanz-Valle, R. (2008). Could HRM support organizational innovation? The International Journal of Human Resource Management, 19(7), 1208-1221.

Kerlinger, F. N., \& Lee, H. B. (2000). Foundations of behavioral research 4th ed. Holt, NY. 
Keskin, H. (2006). Market orientation, learning orientation, and innovation capabilities in SMEs: An extended model. European Journal of innovation management, 9(4), 396417.

Lee, J.-S., \& Hsieh, C.-J. (2010). A research in relating entrepreneurship, marketing capability, innovative capability and sustained competitive advantage. Journal of Business \& Economics Research, 8(9), 109-119.

Lin, C.-H., Peng, C.-H., \& Kao, D. T. (2008). The innovativeness effect of market orientation and learning orientation on business performance. International journal of manpower, 29(8), 752-772.

Ling, T. C., \& Mohd Nasurdin, A. (2010). Human resource management practices and organizational innovation: An empirical study in Malaysia. Journal of Applied Business Research, 26(4), 105.

Lopez-Cabrales, A., Pérez-Luño, A., \& Cabrera, R. V. (2009). Knowledge as a mediator between HRM practices and innovative activity. Human Resource Management: Published in Cooperation with the School of Business Administration, The University of Michigan and in alliance with the Society of Human Resources Management, 48(4), 485-503.

Love, J. H., \& Roper, S. (2015). SME innovation, exporting and growth: A review of existing evidence. International small business journal, 33(1), 28-48.

Lu, K., Zhu, J., \& Bao, H. (2015). High-performance human resource management and firm performance: The mediating role of innovation in China. Industrial Management \& Data Systems, 115(2), 353-382.

Luk, C.-L., Yau, O. H., Sin, L. Y., Alan, C., Chow, R. P., \& Lee, J. S. (2008). The effects of social capital and organizational innovativeness in different institutional contexts. Journal of international business studies, 39(4), 589-612.

Mafabi, S., Munene, J. C., \& Ahiauzu, A. (2015). Creative climate and organisational resilience: the mediating role of innovation. International Journal of Organizational Analysis, 23(4), 564-587.

Martínez-Costa, M., Jimenez-Jimenez, D., \& Castro-del-Rosario, Y. D. P. (2018). The performance implications of the UNE 166.000 standardised innovation management system. European Journal of Innovation Management.

Mavondo, F. T., Chimhanzi, J., \& Stewart, J. (2005). Learning orientation and market orientation: Relationship with innovation, human resource practices and performance. European journal of marketing, 39(11/12), 1235-1263.

Ar, M. I., \& Baki, B. (2011). Antecedents and performance impacts of product versus process innovation: Empirical evidence from SMEs located in Turkish science and technology parks. European Journal of Innovation Management, 14(2), 172-206.

Nasution, H. N., Mavondo, F. T., Matanda, M. J., \& Ndubisi, N. O. (2011). Entrepreneurship: Its relationship with market orientation and learning orientation and as antecedents to innovation and customer value. Industrial Marketing Management, 40(3), 336-345.

Osman, I., \& Galang, M. C. (2011). Are human resource departments really important? An empirical study on Malaysian small and medium enterprises (SMEs) in the service sector. International Journal of business and Management, 6(2), 147.

Rhee, J., Park, T., \& Lee, D. H. (2010). Drivers of innovativeness and performance for innovative SMEs in South Korea: Mediation of learning orientation. Technovation, 30(1), 65-75. 
Rosenbusch, N., Brinckmann, J., \& Bausch, A. (2011). Is innovation always beneficial? A metaanalysis of the relationship between innovation and performance in SMEs. Journal of business Venturing, 26(4), 441-457.

Sekaran, U., \& Bougie, R. (2016). Research methods for business: A skill building approach: John Wiley \& Sons.

Shipton, H., West, M. A., Dawson, J., Birdi, K., \& Patterson, M. (2006). HRM as a predictor of innovation. Human resource management journal, 16(1), 3-27.

Siengthai, S., \& Bechter, C. (2001). Strategic human resource management and firm innovation. Research and Practice in Human Resource Management, 9(1), 35-57.

Smith, A., Courvisanos, J., Tuck, J., \& McEachern, S. (2011). Building Innovation Capacity: The Role of Human Capital Formation in Enterprises--A Review of the Literature. Occasional Paper: ERIC.

Tajeddini, K. (2010). Effect of customer orientation and entrepreneurial orientation on innovativeness: Evidence from the hotel industry in Switzerland. Tourism management, 31(2), 221-231.

Laere, V. K., \& Heene, A. (2003). Social networks as a source of competitive advantage for the firm. Journal of Workplace Learning, 15(6), 248-258.

Vermeulen, P. A., Jong, D. J. P., \& O'shaughnessy, K. (2005). Identifying key determinants for new product introductions and firm performance in small service firms. The Service Industries Journal, 25(5), 625-640.

Vincent, L. H., Bharadwaj, S. G., \& Challagalla, G. N. (2004). Does innovation mediate firm performance?: a meta-analysis of determinants and consequences of organizational innovation.

Vlachos, I. P. (2009). High-performance workplace practices for Greek companies. EuroMed Journal of Business, 4(1), 21-39.

Wahab, A. (2016). Factors determining perceived job performance of University leaders in Pakistan. Universiti Utara Malaysia.

Walter, A., Auer, M., \& Ritter, T. (2006). The impact of network capabilities and entrepreneurial orientation on university spin-off performance. Journal of business Venturing, 21(4), 541-567.

Wang, H.-K., Yen, Y.-F., Tsai, C.-F., \& Lin, Y.-C. (2008). An empirical research on the relationship between human capital and innovative capability: A study on Taiwan's commercial banks. Total Quality Management, 19(11), 1189-1205.

Zakaria, N., Ishak, K., Arshad, D., Abdullah, N., \& Ahmad, N. (2018). Measuring the dimensionality of human resource management: The perspective of Malaysian SME owner-managers. Management Science Letters, 8(5), 317-326. 